\title{
Psalms 69:33-34 in the light of the poor in the Psalter as a whole
}

A Groenewald

(University of Pretoria)

\section{ABSTRACT}

\section{Psalms 69:33-34 in the light of the poor in the Psalter as a whole}

The Psalter has very often been regarded as the prayer book of the poor. In the Psalms God is portrayed as the saviour of the poor, their hope, their stronghold and liberator - whether these are prayers of an individual or prayers of the community. The high concentration of the term(s) for the "poor" in the Psalter, in relation to the rest of the books of the Old Testament (OT), indeed indicates a profound affinity for the "poor" in the Psalter, which is an indication that the Psalter underwent a redaction of the "theology of the poor". In this article the focus will be on Psalm 69, as it seems to have undergone a "redaction of the poor". The main focus will be on the verses 33 and 34, as they, specifically, contain terminology of the "poor". Special attention will also be given to the different terms used for the poor in this text.

\section{INTRODUCTION}

At least one out of every fifth person in our world today falls below any reasonable poverty line. It seems that within a few years, the percentage is estimated to top $25 \%$ of the global population (Blomberg 1999:17). The poor are often the victims of natural disasters, famine or drought. In addition to suffering from a lack of income, the poor are often uneducated, or afflicted with physical illness, political oppression and/or religious persecution. The majority of the world's poor live in rural areas or villages. Countless others have left these areas for the metropolises hoping to find a better life - however, only a handful will ever find it.

The Psalter has very often been regarded as the prayer book of the poor (McPolin 1989:79). In the Psalms God is portrayed as the saviour of the poor, their hope, their stronghold and liberator whether these are prayers of an individual or prayers of the community. The high concentration of the term(s) for the "poor" in the Psalter, in relation to the rest of the books of the Old Testament (OT), indeed indicates a profound affinity for the "poor" in the Psalter. According to Berges $(1999 \mathrm{a}: 14-15,19)$ this is undoubtedly 
an indication that the Psalter underwent a redaction of the "theology of the poor". It is thus not surprising that the Psalter is regarded more and more as the prayer and meditation book of the small $\mathrm{man} /$ person, that is the marginalised.

In this article the focus will be on Psalm 69, as it seems to have undergone a "redaction of the poor". The main focus will be on verses 33 and 34, as they, specifically, contain terminology of the "poor". Special attention will also be given to these terms.

\section{PSALM 69:33A-33B ${ }^{1}$}

The vow to praise, which occurs in verses $31-32$, is followed by the accomplishment of the praise, which is in the form of blessings or well-wishes. This section positions the whole prayer in the midst of a community regarding itself as "miserable" (Gerstenberger 2001:51). Consolation is now promised to a group of the "anâwim ("poor"). The emphasis has thus shifted from the individual supplicant - who is described as "ann ("poor" - 30a) - to the community who is described as 'an $\bar{a} w$ (33a). Colon 33a commences with the verb rā' $\hat{u}$ ("they see"), which is directly followed by the subject ('anāwîm "poor" $)^{2}$. Noticeable is the fact that this colon contains a second verb (yiśmāĥu - "they will rejoice"). The subject is thus both preceded as well as followed by a verb, which are both applicable to the same subject ('anāwîm).

Colon $33 \mathrm{~b}$ builds upon the statement which was made in colon 33a. The group of the "anâwîm ("poor") is now furthermore specified with the honorary title dôrše Elohim ("those who seek God"), which is a designation for the faithful and the pious ${ }^{3}$. They, because they seek God, can expect to receive salvation ${ }^{4}$. However, in contrast to 33a where the supplicant speaks about the 'anāwîm in the third person, they are now addressed directly by means of a jussive, which is an encouragement in the second person (wîh $\hat{\imath}$ - "and let

1 Psalm 69:33ab reads as follows: "The poor see - they will rejoice; you who seek God, let your heart live".

2 This term alludes to the occurrence of ' $\bar{a} n \hat{\imath}$ ("overwhelmed by want, poor, afflicted") in 30a.

3 Cf also Pss 22:27; 70:5; 105:3; 119:2.

4 Cf Westermann (1960:26): “denen, die Jahwe suchen, kann Heil zugesagt werden". 
live" $)^{5}$. It is noticeable that for the first time in this psalm a jussive (command) is not directed towards the deity anymore. The subject occurs at the end of the colon ("your heart"); the pronominal suffix 2 male plural links the subject to the vocative occurring at the beginning of the colon (dôršê Elohim - "those who seek God").

In these cola the individual vow of praise, which has started in $31 \mathrm{ab}$, is now extended to include the community as well. ${ }^{6}$ The supplicant, who is singing this song of praise (tôda $h$ ), is attached to a group which is now identified in these cola as the "anâwim ("poor") and the dôršê Elohim ("those who seek God") (cf Levin 1993:374). One can even assume that the supplicant is not only bound to this group but also represents this group, that is to say he functions as exemplum of the group. This supplicant is hereby placed on the same level with those who share a common need for Yahweh's help and likewise have come to seek his aid. The confession of confidence on the part of the individual is offered as a basis for the trust of the community ${ }^{7}$. The community can thus (re-)discover itself in the fate of the individual sufferer, his tribulation, his being threatened by the enemy as well as his trust ${ }^{8}$. The emphasis is thus not upon the (grammatical) individual anymore, as has been the case in the preceding part of the psalm, but has shifted to the group/the community ${ }^{9}$.

$5 \quad$ According to Kraus (1979:206) "wessen Leben bedroht ist, der ist darauf angewiesen, daß Jahwe sich erbarmend ihm zuwendet und ihm Gutes antut, so daß er wieder auflebt".

6 In this regard Sedlmeier (1996:114) infers as follows: "zwar ist die Ausweitung auf das Kollektiv hin, die in V. 33 beginnt, auch für die Toda der individuellen Klage-psalmen kennzeichnend". Cf also Albertz 1994:508-11; Gamberoni 1986:107-8; Gerleman 1982:41 and Gerstenberger 1996:75.

7 Cf Erbele-Küster (2001:177): "Der Beter erkennt, daß Gott zugunsten der Angefeindeten und Bedrückten rettend eingreift".

8 Cf also Seidl (1999:247): “Die Einzelerfahrung wird zur Erfahrung der Gesamtgruppe".

9 Gerleman (1982:33-49) formulates this assumption as follows: "Der 'Einzelne' ist hier zunächst nicht ein Individuum, sondern ein Typus, Vertreter eines Kollektivs ... Daß das Schicksal des Psalmisten und das eines größeren Menschenkreises in diesen und vielen anderen Psalmen eng aufeinander bezogen sind, ist offensichtlich ... Der 'Einzelne', der hier erscheint, wird als exemplum der vielen angeschaut. Seine Rettung soll vorbildlich als Heilszusage ... verstanden werden". 
These people in all likelihood stand around the supplicant as he is citing or singing this song of praise $(t \hat{o} d \bar{a} h)^{10}$. In these cola the supplicant thus addresses the humble folk, those who lack the material wealth and power to exercise much authority in ordinary human affairs but who are faithful to Yahweh and seek his presence. Their deliverance and prosperity depend upon divine action. They are encouraged by the supplicant to revive their hearts, that is to let their inner vitality as well as inner volition be quickened into new life by confidence in the work of Yahweh (cf Kraus 1979:191 and Tate 1990:200). They surely have no other claim to salvation except the fact that Yahweh, who is a God of hesed (14b.17b), would be denying himself if he, in the long term, would keep on overlooking the crying of the poor (i.e. "connective justice")". Therefore they time and again anticipate his ultimate mercy for the oppressed in eschatological songs of praise ${ }^{12}$. In the subsequent section I will focus in greater detail on the two terms for the poor that occur in Psalm 69:33ab, namely 'ānî and 'anāw.

\section{ANI / ANAW: AN OUTLINE}

The adjective 'anāw (pl. 'anāwîm - "poor") occurs 21 times in the OT, of which 12 times in the Psalter; and the adjective 'antî (Ps 69:30a) occurs 75 times in the whole of the OT, of which 30 times in the Psalter ${ }^{13}$. The question of the meaning of the terms for "poor" has generated considerable debate ${ }^{14}$. Much of the discussion has centred

10 Gunkel \& Begrich (1998:200). Cf also Becker (1966:45): “auch der in v. 33 ausgesprochene Hinweis auf die Festgemeinde, die den Dankenden umringt ....".

11 Cf in this regard Groenewald (2002) for a discussion of the concept "connective justice".

12 Westermann (1977:109) makes use of the term "eschatologisches Loblied". In this regard he infers as follows: "Diese eschatologischen Loblieder sind gewissermaßen das Echo der Gemeinde auf die von Gott her ergangene Heilszusage ... jedoch hat er sowohl geschichtlich als auch theologisch als auch nach dem Vorkommen seine feste Verankerung in der Prophetie des II. Jesaja, in der ja auch abgesehen von dieser Form das Reden der Psalmen und der Sprache der Propheten einander begegnen" (Westermann 1977:109-10). Cf also Albertz (1994:520) and Hermisson (2002:92-104).

13 Martin-Achard (1997:933-4). Cf also Berges (2000:232) and Schwantes (1977:35-38).

14 This outline, however, does not aim to give an overview of this whole debate. Comprehensive accounts of the history of this debate occur in 
around the relationship between the two terms ' $\bar{a} n \hat{\imath}$ and 'anāw which both occur in Psalm 69, and respectively in cola 30a and 33a. The whole controversial issue in this debate was whether 'ann indicates a person who is "socially weak and poor" and whether

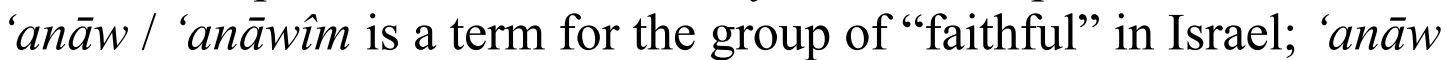
in this sense was regarded as parallel to $s d y q$ ("righteous") and hsd ("faithful") (cf Schultz 1973:133-8). This debate has, however, lost its attractiveness as the confidence in etymological deductions has gradually been discarded (Berges 1999a:14-15). Martin-Achard $(1997: 934)^{15}$ therefore infers that 'an $\bar{w} w$ is fundamentally indistinct from 'ān̂ in meaning: "poor, lowly, bowed down, insignificant, humble", and even "meek". These terms are used interchangeably and can express both material or spiritual poverty (cf McPolin 1989:81-82). They are thus appropriate for those who are humbled through all kinds of material oppression, and in these cases, they depict not only physical suffering, but also a poverty of spirit which demonstrates complete dependence upon God as he is the one who can offer relief of the deep religious needs which the vicissitudes of life present.

Both 'ānî and 'anāw are associated with the terms 'ebyôn ("needy" - 34a) ${ }^{16}$ and dal ("insignificant, poor, helpless"). They are furthermore also associated with "those who seek God" (dôř̌ $\hat{e}$ Elohim - 33b). In line with this, Blomberg (1999:61) postulates that the psalms manifest the beginning of a recurrent equation between the materially poor and the pious person. Accordingly, the 'ann $\hat{\imath}$ and 'an $\bar{a} w$ are distinct from the proud, the mockers and the evildoers. Therefore these adjectives, first of all, do not anymore indicate the "poor" in as far as they are economically deprived, but in as far as they can reckon on an 'ethical imperative' (Berges 2000:233; Gillingham 1988/89:16 and Lohfink 1997:333). The "poor" - even

Birkeland (1933:14-20); Croft (1987:49-53); Dickson (1993:15-37); Fleischer (1989:272-4); Lohfink (1986:155-61, 170-3); Rahlfs (1892:53-88); Schultz (1973:5-20); Van der Ploeg (1950:236-42).

15 Cf also Gerstenberger (1989:263-7).

16 The fact that the two terms 'annî and 'ebyôn constitute a word-pair and occur often in the OT is an indication of the close connection existing between them (cf Prinsloo 1998:397). See, for example, Deut 24:14; Jer 22:16; Ezek 16:49; 18:12; 22:29; Pss 37:14; 40:18; 70:6; 86:1; 109:16.22; Job 24:4.14; Prov. 31:9. 
when indicating themselves as 'annî and 'an $\bar{a} w$ - can lay claim to assistance, which in this instance is divine assistance.

The high concentration of the two adjectives 'anni and 'anāw in the Psalter in relation to the rest of the books of the OT has already been referred to ${ }^{17}$. Significant is that one-fifth of the psalms contains references to the poor; this fact indicates a profound affinity for the "poor" in the Psalter ${ }^{18}$. According to Berges $(1999 \mathrm{a}: 14-15,19)$ this is a sign that the Psalter underwent a redaction of the "theology of the poor". It is thus not surprising that the Psalter is regarded more and more as the prayer and meditation book of the small man, the marginalised, who had a critical view of the post-exilic temple aristocracy as well as their position of power. The Psalter rather functioned as a "Volksbuch für Laien ..., das als »fromme" und »konservative « Kurzfassung von Tora und Nebiim gelesen, gelernt und gelebt werden konnte" (Zenger 2006:367). The perception that the Psalter functioned as the cultic songbook of the second temple has thus finally been rejected (Füglister 1988:337). Zenger (1998:35) furthermore infers "der Psalter als Ganzer (und im übrigen bereits die meisten Teilsammlungen, die in ihm integriert sind) hat originär einen nicht-liturgischen und kultunabhängigen »Sitz im Leben«". The supplicants of the psalms thus did not find protection in the cult first of all, but rather in the praises of the psalms which ascend to Yahweh, the king of the world, who had established his just rule on mount Zion (Berges 1999a:15).

According to Albertz (1994:518ff) the social and religious split experienced by the Judahite community in the second half of the fifth century as the result of an economic crisis, in all probability led to the formation of a special personal piety in the impoverished lower classes. There is enough evidence indicating the marginalisation of these poorer religious classes in society. This caused the development of a specific kind of personal piety in these classes, namely the so-called "piety of the poor". The most important task of this theology of the "piety of the poor", which was developed and practised in these communities, was to restore dignity as well as

17 Noteworthy is the fact that the second highest occurrence of ' $\bar{a} n \hat{\imath} /$ ' $a n \bar{a} w$ occurs in the book of Isaiah, which indicates a close interrelatedness between the Psalter and the book of Isaiah (cf. Berges 1999b:159f).

18 The only exception is the fourth book of the Psalms (Pss. 90-106) where this theme does not play such an important role. 
hope to the oppressed victims of the social crisis. This function of this theology explains why the social terms for "poor" took on a religious undertone in the piety of the poor. However, what is meant here is not a religious transfiguration of poverty, but religious compensation for a social lack. According to their own selfunderstanding, they were not on the periphery of the community, but they formed the core (Albertz 1994:522). This assumption gave them the power to assert themselves within the community of Judah, despite their social marginalisation. They indeed even gained influence over the community as a whole with their "piety of the poor". This influence is, among other things, to be recognised in the redaction of the Psalter, namely a redaction characterised by the "theology of the poor".

\section{PSALM 69:34A-34B ${ }^{19}$}

In these cola the praise, which commenced in cola $33 \mathrm{ab}$, continues. It is in the form of a reflection upon God's relationship to the poor, and is thus still part of the eschatological song of praise. Colon $34 \mathrm{a}$ commences with the conjunction $k \hat{\imath}$, through which it is closely linked to the preceding cola. The aforementioned proclamation and call-up are now established in the person of Yahweh. The conjunction thus has a causal function: it introduces additional grounds for the supplicant to sing the song of praise (tôdāh-31b). The conjunction is linked to the participle šome' $a$ ("listens") by means of the maqqeph. Yahweh functions as the subject and occurs in the final position of the colon. It is congruent in both gender and number to the participle šóme' $a$ (male singular); an identification of subject and predicate with one another is thus established. The participle is then furthermore qualified by the prepositional object ('ebyônim), as it governs the prepositional object (cf. Tillmann 1993:89). The participle ( $\left.\check{s}^{\prime} \bar{m} \bar{e}^{-} ' a\right)$ fulfils a very important function in this colon: it namely emphasises continued uninterrupted activity which, in this particular instance, is Yahweh's act of listening to the needy, that is to say to give a favourable hearing to the needy ${ }^{20}$. It

19 This text reads as follows: "For Yahweh always listens to the needy, and he does not despise his captives".

20 In this regard Waltke \& O'Connor (1990:624) postulates that the use of the participle is, among other things, to emphasise durative circumstances. The state of affairs involves repeated facts as well as action, rather than a particular event. According to Gesenius (1910:355-6 § 116a) "the participle active 
thus indeed stresses the fact that Yahweh is listening to his needy those who are dependent on him - is guaranteed and is also of a perpetual nature ${ }^{21}$.

Cola 34a and 34b are syndetically linked together. The object occurs in the first position ("sîrāyw - "his captives") and is indicated by means of the nota objecti. The pronominal suffix 2 male singular attached to the object ( $\left.{ }^{a} s \hat{i} r \bar{y} y w\right)$, refers back to Yahweh,

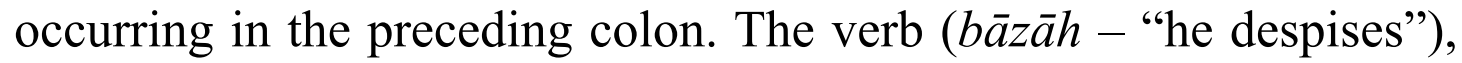
which occurs in the final position, is negated by means of the negative particle. The negative formulation of divine concern is quite striking: it has an undertone of challenge (Albertz 1994:646). Yahweh is actually in a way challenged to prove that he does not despise his prisoners, that is to say "his own who are in bonds". Although the word "sîrim ("captives") is normally rendered as "prisoners", it can also refer to those who are suffering and in affliction, or who are economically bound ${ }^{22}$. It is thus not always befitting to be interpreted literally as "prisoners"23. Johnson (1979:395-396) wisely warns against taking the "captives" (or "bonds") in this colon too literally. This approach relates well to the desperate struggle with deadly conditions which are graphically described in Psalm 69:2a-3d and Psalm 69:15a-16c. If this colon is seen in connection with Psalm 69:5ef, which states the fact that the

indicates a person or thing conceived as being in the continual uninterrupted exercise of an activity".

21 Arambarri (1990:145) analyses this colon as follows: "Die Erhörung war bisher immer die Antwort auf eine konkrete Notlage gewesen; in diesem Text dagegen ist eine allgemeine Überzeugung oder theologische Aussage vorhanden. Auch das Partizip betont eine Eigenschaft (= Jahwe ist einer, der für die Armen eine Antwort hat)".

22 Cf. for example Isa. 61:1: "The spirit of the Lord God is upon me, because the Lord has anointed me; he has sent me to bring good news to the oppressed, to bind up the brokenhearted, to proclaim liberty to the captives, and release to the prisoners" (NRSV).

23 Gesenius (1962:55) renders it, over and above "Gefangenen", as "leidenden Israeliten". Some exegetes, however, see this colon as referring to the exilic Judahites. On the basis of this interpretation they therefore ascribe this text to either the late exilic or early post-exilic period (cf. Delitzsch 1894:472; Herkenne 1936:238; Lindström 1994:224; Mays 1994:232; Ridderbos 1958:215; Sedlmeier 1996:115, 158; Tate 1990:200; Van Uchelen 1977:212). 
supplicant is innocently accused of theft, the term ${ }^{a}$ sirîm can be an indication of people or a group who regard themselves as captives of their persecutors (Cf. Becker 1966:45; Bratcher \& Reyburn 1991:607 and Seybold 1996:270). It is thus rather a figure of the bonds of suffering and oppression. It indicates those who are captives of a bleak situation in which they find themselves. In this sense ${ }^{a}$ sîrim must be read and interpreted as synonymous with "anāwîm ("poor"), dôršê Elohim ("those who seek God") and 'ebyônîm ("needy") (Botterweck 1974:38 and Dahood 1970:165).

These two cola (34a and $34 \mathrm{~b}$ ) thus cite an additional justification for the supplicant to praise the name of God. Although they contain other arguments, they are still linked to the preceding cola by means of the conjunction $k \hat{\imath}$ which indeed indicates a further development of the preceding arguments. These cola furthermore recount the divine benefaction the supplicant is sure to experience. This implies a transaction between Yahweh and the human world, which is recounted in the $k \hat{k}$-clause (Mayer 1986:433-434). Because the $k \hat{\imath}$-clause follows a summons to praise, it constitutes a statement about Yahweh. The group of the 'anāwim ("poor") is furthermore identified by means of two honorary attributes, namely the 'ebyônim ("the needy/poor") and "sîrāyy ("his captives", viz. Yahweh's captives). We can thus presume that because Yahweh always listens to the needy and does not despise any of his prisoners (34ab), the poor will be a witness of this beneficial action of Yahweh, they will rejoice and as a result will let their heart live. The justification for the tôdāh (31b) is thus based on Yahweh's faithful action towards the needy $(34 \mathrm{ab})^{24}$.

\section{5 'EBYÔN: AN OUTLINE}

The noun 'ebyôn (pl. 'ebyônim) occurs 61 times in the OT, of which 23 times in the Psalter (Botterweck 1974:29 \& Gerstenberger 1997:16). It belongs to a series of words which describe the socially weak and/or poverty. Words belonging to the same semantic field

24 See also Berges (2000:233), who in this regard infers as follows: "De drie theo-politieke begrippen dal, ebjôn en ani/anaw getuigen van een groeiende betrokkenheid op de ethische sfeer, waarvoor JHWH zelf borg staat en waarvan Hij de behoeder is. Arm-zijn wordt steeds meer - wat boven de economische nood uitgaat - een 'rechts-grond', die JHWH, de God van de bevrijding, in het geding brengt. Wat toegespitst kan men zeggen: overal waar de armen zijn, speelt ook JHWH een rol". 
include 'ān̂ (30a) and 'anāw (33a), which both occur in this psalm; as well as other terms which do not occur in this psalm, for example, dal ("insignificant, poor, helpless"), rāš ("poor") ${ }^{25}$, as well as "a $n \hat{\imath}$ ("misery, poverty"). According to McPolin (1989"82) 'ebyôn describes the person who asks ${ }^{26}$. Originally the 'ebyon is the one who seeks alms, that is to say the beggar. Only later on the word was used more generally for the poor and/or needy person. In both the legal as well as prophetic corpus the 'ebyon is portrayed as the exploited. ${ }^{27}$ Wisdom passages, however, often simply have material suffering in mind which stands in contrast to wealth (Spangenberg 1991:250-62. Cf. also Fensham 1962:137).

The manner in which the psalms, in particular, use 'ebyôn confirms the general impression that in Israel, as everywhere else in the Ancient Near East, the socially weak must have had a special relationship to the deity (cf. Lohfink 1987a:129-32 \& Lohfink 1997:333). In this regard Lohfink (1987b:123) infers as follows: "The sun god, appearing under different names according to the different cultures, was everywhere regarded as the god of justice and of a successful human social order. As such, the god had a special affection for the poor" ${ }^{\prime 2}$. Purely on the basis of statistics, we could probably fit the great majority of the OT texts, which speak of the "poor", quite easily into the Ancient Near Eastern picture. However, when the Hebrew world is compared to its social surroundings (Umwelt), an interesting process which took place in this regard is noted. Of course, here we have only one God rather than many. This automatically leads us to the question of who takes care for the poor. Here it is not the sun god who takes the responsibility for the socially weak, but the God of Israel, that is to say Yahweh (Janowski 1999:218-9; see also Prinsloo 1996:479).

25 See Schwantes 1977:16-52 for an extensive discussion of these four preceding terms.

26 It derives from the verb ' $b h$ which can be rendered as "to want, desire".

27 With regard to the legal corpus in the OT see Bosman (1991:210-5) and Gillingham (1988/89:16). With regard to the prophetic corpus compare Van Heerden (1991:241).

28 Cf also Lohfink (1992/3:14); (Einführung III: Die "Armen in Bibel und Umwelt").

29 Examples of sun gods in the ancient Orient are, for example, Shamash in Mesopotamia and Re in Egypt. 
In order to illustrate this process which occurred in the Hebrew world, a brief look will be taken at Psalm 82 . This psalm is not only an important text in a religionsgeschichtliche ("history of religions") respect, but it also gives a clue to a better understanding of the position of the socially weak in Israel ${ }^{30}$. In verse 1 God (Elohim - i.e. Yahweh) is represented anthropomorphically as judge in the midst of the "divine council". His function as judge is explained in greater detail in the following verses (vv 2-4). The irony is that God (Elohim - i.e. Yahweh) is accusing the gods (elōhim) of failing to fulfil their judicial function (v 2). They have judged unjustly and allowed the transgressors to rise to the top of the world's societies. The important part with regard to the position of the socially weak occurs in the verses 3-4, in which God (Yahweh) challenges the gods (elōhim) to let justice be done to the orphans and the poor, as well as to rescue the weak and the needy from the power of the wicked. But the gods have not done that. In verse 5 it is therefore emphatically stated that the gods have no insight, as a consequence of which they cannot be judges. Instead of letting justice prevail, their behaviour caused a total chaos. And because they have failed to accomplish this command, the verdict of death is pronounced over them (vv 6-7), which means that they are deprived of their divinity (cf. also Hossfeld 1998:241). Therefore, they are to be deposed, and Yahweh alone will take over their task. In the last verse (v 8) the supplicant brings to God the victorious command to give justice to the world. It can thus be deduced that the only one who can give justice and deliverance to the weak and the needy is God. The God of Israel (Yahweh) is regarded as the only true judge and protector of the weak $^{31}$. It is furthermore important to take note of the fact that the most important difference between this specific conception in the Hebrew world, and that of Mesopotamia and Egypt, is the fact that

30 Hossfeld \& Zenger (2000:492) formulates this fact as follows: "Ps 82 bleibt einer der spektakulärsten Texte des Alten Testaments, der in seiner Bedeutung bislang wenig erkannt ist. Mit seiner »Definition« des wahren Gottes ... ist der Psalm sowohl religionsgeschichtlich als auch systematischtheologisch originell und singulär".

31 Boshoff (1991:184) analyses this central proposition made in Psalm 82 as follows: "In lyn met die tema van rykdom en armoede is dit interessant dat die maatstaf vir god-wees waarmee Hy die gode beoordeel, is of hulle reg kan laat geskied en die arme kan red". 
the exercising of justice is narrowed down to one God (Yahweh) and all the others are hereby excluded ${ }^{32}$.

The following count as symptoms of "being poor before God": unfortunate circumstances, contempt, persecution, sickness, near death, etcetera (Gerstenberger 1997:18). It thus applies to those who are humbled through all kinds of material oppression, and in these cases, it depicts not only the physical suffering, but also a poverty of spirit which demonstrates complete dependence upon $\operatorname{God}^{33}$. The term 'ebyôn in the psalms is furthermore used to depict what has happened as a result of the malevolent actions of others, rather than describing any particular status of the psalmist/supplicant in question. The 'ebyônim are clearly distinct to those who are in authority, to the oppressors, the mighty, the evildoers and the wicked (Berges 2000:232). It is indeed to be seen as a stereotyped term which refers to all who have been deprived of their rights, and so must wait for God alone, for he is the only source of vindication. It is thus apparent that Yahweh is portrayed as the deliverer of the 'ebyônim (Botterweck 1974:38-40). In most of the individual psalms of lament, like in Psalm 69, the believing hope and the certainty that Yahweh will give a favourable hearing is expressed by referring to his divine deliverance. This hope and confidence is based on the 'ebyôn's faith in God, namely the fact that he is abundant in steadfast love (69:14b.17b) and full of mercy (69:17c). The 'ebyôn ("needy/poor") thus relies on Yahweh to reciprocate his enemies $(69: 23 a-29 b)$, to turn to him $(69: 17 \mathrm{c})$, not to hide his face from him $(69: 18 \mathrm{a})$ and to hear his prayer $(69: 14 \mathrm{~b} .17 \mathrm{a} .18 \mathrm{c})$ in the faithfulness of his salvation $(69: 14 b)$.

\section{CONCLUSION}

In general the Psalms are sincere expressions of feeling. They are cries of the heart to God expressing fundamental attitudes towards God and human life. The cry of the poor is a calling on God and also a cry of deep distress. The poor and the needy implore God to hear and answer them in their distress and their petition is one of trust.

32 Cf. also Fensham (1962:130-135); Krawczack (2001:52); Labuschagne (1966:83f); Lohfink (1994:7); Loretz (2002:276); W S Prinsloo (1995:227; 2000:118) and Stendebach (1986:439).

33 Cf Berges (2000:232): "De connotatie 'behoeftig zijn' die meeklinkt in het woord ebjôn is van het sociale niveau overgedragen op het religieuze vlak". 
God is thus never so absent for the poor that God cannot be present to their outcry, so that they can express their belief that there is always hope for the poor.

In this article the focus was on Psalm 69:33-34 in view of the terminology of the poor used in this text. Attention was given to the terms ' $\bar{a} n \hat{\imath} /$ 'an $\bar{a} w$ (pl. 'an $\bar{a} w \hat{\imath} m$ ) and 'ebyôn - specifically on the way they function within the context of Psalm 69. It seems that these verses undergone a "redaction of the poor", that is they reflect the "piety of the poor". This development in the literary history of ancient Israel had the task to restore dignity, as well as hope for those in the Judahite society who regarded themselves to be victims of the social crisis during the fifth century.

\section{Consulted literature}

Albertz, R 1994. A history of Israelite religion in the Old Testament period. Vol. I: From the beginnings to the end of the monarchy. Vol. II: From the exile to the Maccabees. London: SCM Press (OTL.)

Arambarri, J 1990. Der Wortstamm »hören « im Alten Testament. Semantik und Syntax eines hebräischen Verbs. Stuttgart: Katholisches Bibelwerk (SBB).

Becker, J 1966. Israel deutet seine Psalmen. Stuttgart: Katholisches Bibelwerk (SBS 18).

Berges, U 1999a. De armen van het boek Jesaja. Een bijdrage tot de literatuurgeschiedenis van het Oude Testament. Nijmegen: Katholieke Universiteit Nijmegen.

-, 1999b. Die Armen im Buch Jesaja. Ein Beitrag zur Literaturgeschichte des AT. Biblica 80(2), 153-177.

-, 2000. Armoede en haar bestrijding in de wetten van het Oude Testament. Tijdschrift voor Theologie 40(3), 227-250.

Birkeland, H 1933. 'Anî und 'Anaw in den Psalmen. Oslo: A W Brøggers Boktrykkeri.

Blomberg, C L 1999. Neither poverty nor riches. A biblical theology of material possessions. Leicester: Apollo (New Studies in Biblical Theology 7).

Boshoff, W 1991. God, gode en gelowiges: opvattings oor God in die godsdiensgeskiedenis van Israel, in: Bosman, H L et al (red), Purper en flenterlap. Rykdom en armoede in die Ou Testament, 180-200. Pretoria: J L van Schaik.

Bosman, H L 1991. "So iets word nie in Israel gedoen nie". Die regspraak in oud-Israel, in: Bosman, H L et al (red), Purper en flenterlap. Rykdom en armoede in die Ou Testament, 202-219. Pretoria: J L van Schaik.

Botterweck, G J 1974. Art. ebjôn. TDOT I, 27-41. 
Bratcher, R G \& Reyburn W D 1991. A translator's handbook on the book of Psalms. New York: United Bible Societies.

Croft, S J L 1987. The identity of the individual in the psalms. Sheffield: Sheffield Academic Press (JSOT SS44).

Dahood, M 1970. Psalms II, 51-100. New York: Doubleday \& Company (AB 17).

Delitzsch, F ${ }^{5}$ 1894. Biblischer Kommentar über die Psalmen. Leipzig: Dörffling \& Franke (BKAT 4,1).

Dickson, C R 1993. Poverty as powerlessness: an exegetical study of the meaning of the Hebrew terminology for the poor in Psalm 82. Unpublished MA-thesis. Pretoria: University of Pretoria.

Erbele-Küster, D 2001. Lesen als Akt des Betens. Eine Rezeptionsästhetik der Psalmen. Neukirchen-Vluyn: Neukirchener Verlag (WMANT 87).

Fensham, F C 1962. Widow, orphan, and the poor in ancient Near Eastern legal and wisdom literature. Journal of Near Eastern Studies 21, 129-139.

Fleischer, G 1989. Von Menschenverkäufern, Baschankühen und Rechtsverkehrern. Die Sozialkritik des Amosbuches in historisch-kritischer, sozialgeschichtlicher und archäologischer Perspektive. Weinheim: Beltz Athenäum Verlag (BBB 74).

Füglister, N 1988. Die Verwendung und das Verständnis der Psalmen und des Psalters um die Zeitenwende, in: Schreiner, J (Hrsg.), Beiträge zur Psalmenforschung. Psalm 2 und 22, 319-384. Würzburg: Echter Verlag (FzB 60).

Gamberoni, J 1986. Der einzelne in den Psalmen, in: Haag, E \& Hossfeld, F-L (Hrsg.), Freude an der Weisung des Herrn. Beiträge zur Theologie der Psalmen. FS. H Groß, 107-123. Stuttgart: Katholisches Bibelwerk (SBB 13).

Gerleman, G 1982. Der "Einzelne" der Klage- und Dankpsalmen. Vetus Testamentum 32, 33-49.

Gerstenberger, E S 1989. Art. 'nh II. TWAT VI, 247-70.

-, 1996. Welche Öffentlichkeit meinen das Klage- und das Danklied? Jahrbuch für biblische Theologie 11, 69-89. Neukirchen-Vluyn: Neukirchener Verlag.

-, 1997. Art. 'bh. TLOT 1, 15-19.

-, 2001. Psalms (Part 2) and Lamentations. Grand Rapids, Michigan: William B Eerdmans (FOTL 15).

Gesenius, W 2 1910. Gesenius' Hebrew grammar. [Edited and enlarged by E. Kautzsch. Revised by A.E. Cowley.] Oxford: Clarendon Press.

${ }^{17}$ 1962. Hebräisches und aramäisches Handwörterbuch über das Alte Testament [In Verbindung mit H Zimmern, W M Müller und O Weber. Bearbeitet von F. Buhl.] Berlin: Springer-Verlag. 
Gillingham, S 1988/89. The poor in the Psalms. The Expository Times 100, 1519.

Groenewald, A 2002. Psalm 69:23a-30b and divine retribution - a question of Ma'at? OTE 15(3), 657-674.

Gunkel, H \& Begrich, J 1998. Introduction to Psalms. The genres of the religious lyric of Israel. (Translated by J D Nogalski from the fourth edition of "Einleitung in die Psalmen: die Gattungen der religiösen Lyrik Israels", 1. Auflage 1933; $\left.{ }^{4} 1985\right)$. Macon, Georgia: Mercer University Press (MLBSt).

Herkenne, H 1936. Das Buch der Psalmen. Bonn: Peter Hanstein Verlagsbuchhandlung (Die heilige Schrift des Alten Testaments V,2).

Hermisson, H-J 2002. 'Deuterojesaja' und 'Eschatologie', in: Postma, F et al (ed), The new things. Eschatology in Old Testament prophecy. FS. H Leene, 89-105. Maastricht: Shaker Publishing (ACEBT.SS 3).

Hossfeld, F-L 1998. Das Prophetische in den Psalmen. Zur Gottesrede der Asaf-psalmen im Vergleich mit der des ersten und zweiten Davidpsalters, in: Dietrich, F \& Willmes, B (Hrsg.), Ich bewirke das Heil und erschaffe das Unheil (Jesaja 45,7). Studien zur Botschaft der Propheten. FS. L Ruppert, 223-243. Würzburg: Echter Verlag (FzB 88).

Hossfeld, F-L \& Zenger, E 2000. Psalmen 51-100. Freiburg i.B.: Herder (HThKAT).

Janowski, B 1999. JHWH und der Sonnengott. Aspekte der Solarisierung JHWHs in vorexilischer Zeit, in: Janowski, B, Die rettende Gerechtigkeit. Beiträge zur Theologie des Alten Testaments 2, 192-219. Neukirchen-Vluyn: Neukirchener Verlag.

Johnson, A R 1979. The cultic prophet and Israel's psalmody. Cardiff: University of Wales Press.

Kraus, H-J 1979. Theologie der Psalmen. Neukirchen-Vluyn: Neukirchener Verlag (BKAT XV/3).

Krawczack, P 2001. "Es gibt einen Gott, der Richter ist auf Erden!” (Ps 58,12b). Ein exegetischer Beitrag zum Verständnis von Psalm 58. Berlin: Philo (BBB 132).

Labuschagne, C J 1966. The incomparability of Yahweh in the Old Testament. Leiden: E J Brill.

Levin, C 1993. Das Gebetbuch der Gerechten. Literargeschichtliche Beobachtungen am Psalter. Zeitschrift für Theologie und Kirche 90, 355-81.

Lindström, F 1994. Suffering and sin: interpretations of illness in the individual complaint psalms. Stockholm: Almqvist \& Wiksell International.

Lohfink, N 1986. Von der “Anawim-Partei” zur "Kirche der Armen”. Die bibelwissenschaftliche Ahnentafel eines Hauptbegriffs der "Theologie der Befreiung". Biblica 67, 153-175. 
-, 1987a. Gott auf der Seite der Armen. Zur "Option für die Armen" im Alten Orient und in der Bibel, in: Lohfink, N. Das Jüdische am Christentum. Die verlorene Dimension, 122-143. Freiburg: Herder.

-, 1987b. Option for the poor. The basic principle of liberation theology in the light of the Bible. Berkeley, California: Bible Press.

-, 1992/93. Die Armen in den Psalmen. Teil I. Vorlesungsmanuskript Wintersemester 1992/93. Frankfurt am Main: Hochschule Sankt Georgen [with permission of the author].

-, 1994. Die Armen in den Psalmen. Teil II. Vorlesungsmanuskript Sommersemester 1994. Frankfurt am Main: Hochschule Sankt Georgen [with permission of the author].

-, 1997. Drei Arten, von Armut zu sprechen. Illustriert an Psalm 109. Theologie und Philosophie 72, 321-336.

Loretz, O 2002. Psalmstudien. Kolometrie, Strophik und Theologie ausgewählter Psalmen. Berlin: Walter de Gruyter (BZAW 309).

Martin-Achard, R 1997. Art. 'nh II. TLOT 2, 931-7.

Mayer, G et al 1986. Art. Tôdāh; ydh. TDOT V, 427-43.

Mays, J L 1994. Psalms. Louisville, Kentucky: John Knox Press (Interpretation).

McPolin, J 1989. Psalms as prayers of the poor, in: Cathcart, K J \& Healey, J F (ed), Back to the sources. Biblical and near eastern studies. FS. D Ryan, 79103. Dublin: Glendale Press.

Prinsloo, G T M 1996. Yahweh and the poor in Psalm 113: literary motif and/or theological reality? OTE 9(3), 465-85.

-, 1998. Man's word - God's word: a theology of antithesis in Psalm 12. ZAW $110,390-402$.

Prinsloo, W S 1995. Psalm 82: Once again, gods or men? Biblica 76, 219-28.

-, 2000. Die lof van my God solank ek lewe. (Verklaring van 'n aantal psalms deur Willem S Prinsloo). Irene, Pretoria: Medpharm Publikasies.

Rahlfs, A. 1892. Ani und anaw in den Psalmen. Göttingen: Dieterichsche Verlagsbuchhandlung.

Ridderbos, J 1958. De Psalmen II. Psalm 42-106. Kampen: J H Kok (COT).

Schultz, C 1973 'Ani and 'anaw in Psalms. Ann Arbor, Michigan: University Microfilms (Ph.D.-thesis, Brandeis University).

Schwantes, M 1977. Das Recht der Armen. Frankfurt: Peter Lang (Beiträge zur biblischen Exegese und Theologie 4).

Sedlmeier, F 1996. Jerusalem - Jahwes Bau. Untersuchungen zu Komposition und Theologie von Psalm 147. Würzburg: Echter Verlag (FzB 79).

Seidl, T 1999. "Strick ist entzwei und wir sind frei". Ps 124 - Dank und Hoffnung, in: Fuchs, O \& Widl, M (Hrsg.), Ein Haus der Hoffnung. FS. Rolf Zerfaß, 244-251. Düsseldorf: Patmos Verlag. 
Seybold, K 1996. Die Psalmen. Tübingen: J C B Mohr (Paul Siebeck) (HAT $\mathrm{I} / 15$ ).

Spangenberg, I J J 1991. "Die armes sal julle altyd by julle hê". Rykdom en armoede vanuit 'n wysheidsperspektief, in: Bosman, H L et al (red), Purper en flenterlap. Rykdom en armoede in die Ou Testament, 243-262. Pretoria: J $\mathrm{L}$ van Schaik.

Stendebach, F J 1986. Glaube und Ethos. Überlegungen zu Ps 82, in: Haag, E \& Hossfeld, F-L (Hrsg.), Freude an der Weisung des Herrn. Beiträge zur Theologie der Psalmen. FS. H Groß, 425-440. Stuttgart: Katholisches Bibelwerk (SBB 13).

Tate, M E 1990. Psalms 51-100. Dallas, Texas: Word Books Publisher (WBC 20).

Tillmann, N 1993. "Das Wasser bis zum Hals!" - Gestalt, Geschichte und Theologie des 69. Psalms. Altenberge: Oros Verlag (MThA 20).

Van der Ploeg, J P M 1950. Les pauvres d'Israel et leur piété. Oudtestamentische Studiën 7, 236-70.

Van Heerden, W 1991. Profete en profytmakers: profetiese perspektiewe op rykdom en armoede, in: Bosman, $\mathrm{H}$ L et al (red), Purper en flenterlap. Rykdom en armoede in die Ou Testament, 220-242. Pretoria: J L van Schaik.

Van Uchelen, N A 1977. Psalmen. Deel II (41-80). Nijkerk: Uitgeverij G F Callenbach (POT).

Waltke, B K \& O'Connor, M 1990. An introduction to Biblical Hebrew syntax. Winona Lake, Indiana: Eisenbrauns.

Westermann, C 1960. Die Begriffe für Fragen und Suchen im Alten Testament. Kerygma und Dogma. Zeitschrift für theologische Forschung und kirchliche Lehre 6: 2-30.

-, 5 1977. Lob und Klage in den Psalmen. (5. erweiterte Auflage von Das Loben Gottes in den Psalmen). Göttingen: Vandenhoeck \& Ruprecht.

Zenger, E 1998. Der Psalter als Buch, in: Zenger, E (Hrsg.), Der Psalter im Judentum und Christentum, 1-57. Freiburg: Herder (HBS 18).

-, ${ }^{6}$ 2006. Das Buch der Psalmen, in: Zenger, E (Hrsg.), Einleitung in das Alte Testament, 348-370. Stuttgart: W. Kohlhammer (Studienbücher Theologie 1, 1). 